\title{
Effect of early treatment with transcutaneous electrical diaphragmatic stimulation (TEDS) on pulmonary inflammation induced by bleomycin
}

\author{
Laisa A. Santos, Carlos A. Silva, Maria L. O. Polacow
}

\begin{abstract}
Background: Bleomycin (B) is an antineoplastic drug that has pulmonary fibrosis as a side effect. There are few experimental studies about the effects of physical therapy treatment in this case. Objective: The objective was to study rat lungs treated with B and precocious intervention by transcutaneous electrical diaphragmatic stimulation (TEDS). Method: Wistar rats were divided into 4 groups $(n=5)$ : a control group (C); a stimulated group (TEDS); a group treated with a single dose of B (intratracheally, $2.5 \mathrm{mg} / \mathrm{kg}$ ) (B); and a group treated with B and electric stimulation (B + TEDS). After the B instillation, the electrical stimulation was applied for 7 days, for a duration of 20 minutes. Lung fragments were histologically processed with hematoxylin and eosin (HE) and 8-isoprostane-PGF2 $\alpha$ (8-iso-PGF2 $\alpha$ ). The density of the alveolar area was determined by planimetry, the inflammatory profile was defined by the number of cells, and the level of oxidative stress in the pulmonary tissue was evaluated by 8-iso-PGF2 $\alpha$. For statistical analysis of the data, the Shapiro-Wilk test was used, followed by a one-way ANOVA with the post-hoc Bonferroni test ( $\mathrm{p} \leq 0.05)$. Results: The B group exhibited a significant reduction in the area density, and the acute treatment with B + TEDS prevented this reduction. There were increased numbers of fibroblasts, leukocytes, and macrophages in the B group, as well as increased lipid peroxidation, which was observed only in this group. Conclusion: B promoted a reduction in the alveolar density area, thereby inducing the inflammatory process and increasing the production of free radicals. These effects were minimized by the application of TEDS at the initial treatment stage.
\end{abstract}

Keywords: physical therapy; electric stimulation; diaphragm; bleomycin; pulmonary fibrosis.

\section{HOW TO CITE THIS ARTICLE}

Santos LA, Silva CA, Polacow MLO. Effect of early treatment with transcutaneous electrical diaphragmatic stimulation (TEDS) on pulmonary inflammation induced by bleomycin. Braz J Phys Ther. 2013 Nov-Dec; 17(6):606-613. http://dx.doi.org/10.1590/ S1413-35552012005000130

\section{Introduction}

Bleomycin (B) is a chemotherapeutic antibiotic used for treating lymphomas, testicular tumors, and carcinomas. This drug can produce a number of lesions associated with functional and biochemical changes that promote pulmonary fibrosis, depending on the dose ${ }^{1}$. The microscopic tissue changes include the following: bronchial metaplasia, reactive macrophages, atypical alveolar epithelial cells, fibrinous edema, and interstitial fibrosis ${ }^{2}$. The main consequence is damage to the endothelial cells of the pulmonary vessels, which leads to the formation of certain cytokines and reactive oxygen species (ROS) ${ }^{3}$.

The pulmonary fibrosis induced by $\mathrm{B}$ in rats and mice is a useful tool to assess the general mechanisms of fibrosis, especially those mechanisms mediated by $\operatorname{ROS}^{2,4}$. The production of ROS can increase lung damage via antiprotease inactivation, membrane rupture, and alveolar damage ${ }^{5}$.

Costa et al. $^{6}$ evaluated the effects of B through energetic metabolism, thiobarbituric acid-reactivesubstances (TBARS), and biochemical analysis in rats. The authors concluded that this drug causes an adaptive response of the respiratory muscles, represented by an increase in TBARS and glycogen concentration.

This same group of researchers associated the model of pulmonary fibrosis in rats with the transcutaneous electrical diaphragmatic stimulation (TEDS) treatment to analyze the respiratory muscles ${ }^{7}$. The effectiveness of this physical therapeutic method was also observed in the improved energetic conditions of the diaphragm, as well as changes in the fiber type ${ }^{8}$. 
TEDS is a specific method used to improve ventilatory function, thereby assisting patients who have respiratory muscle weakness or have undergone mechanical ventilation ${ }^{9}$. Certain studies have demonstrated benefits, such as increased respiratory muscle strength ${ }^{10,11}$.

However, the effect of this treatment on pulmonary tissue altered by inflammatory reaction has not yet been studied. Despite the specific effect on the diaphragmatic muscle, the emergent hypothesis is that muscle contraction can intervene in the pulmonary tissue during the acute phase of pathological conditions, once physical exercise has been proved beneficial on the oxidative stress in that situation ${ }^{12}$.

Thus, TEDS may be a complementary resource during physical therapy to minimize or prevent the deleterious effects of B on the lung. As stated, the objective of the present study was to evaluate the effect of B and the association of this drug with early TEDS treatment in the lung parenchyma of Wistar rats.

\section{- Method}

This study was approved by the Ethics Committee on Animal Use of the Federal University of São Carlos (Comissão de Ética no Uso de Animais da Universidade Federal de São Carlos - CEUA/ UFSCar), São Carlos, SP, Brazil, protocol No. 011/2011. Twenty male Wistar rats, between 3 and 4 months of age, with a mean body weight of $263.4 \pm 45.5 \mathrm{~g}$, and with food and water $a d$ libitum, were used. The rats were divided into four experimental groups with five animals in each group, as follows: a control (C) group, a stimulated (TEDS) group, a group treated with $\mathrm{B}(\mathrm{B})$, and a group treated with B combined with TEDS (B + TEDS).

\section{Treatment}

\section{Bleomycin}

The B treatment was conducted using a single dose of B sulfate (BONAR ${ }^{\circledR} 15 \mathrm{U}$ - Biosintética): $8.57 \mathrm{mg}$ of lyophilic powder with vehicle: water for injection at a $2.5 \mathrm{mg} / \mathrm{kg}$ of body weight concentration, for a total of $0.2 \mathrm{~mL}$ per animal through the intratracheal route, according to the protocol of Beller et al. ${ }^{13}$ The animal was held by the back of the body for immobilization, and the animal's tongue was fixed with the aid of tweezers, making the procedure easier. A cannula with a rounded tip was attached to a syringe and introduced into the oral cavity through the epiglottis until contact was made with the tracheal rings, thereby confirming the location of the cannula, which was inserted carefully.

\section{Respiratory muscle training}

For treatment with TEDS, the protocol of Costa et al. ${ }^{8}$ was used, and the first session was performed 24 hours after the B administration. The animals were anesthetized with a mixture of Dopalen $^{\circledR}$ (ketamine hydrochloride) $1.16 \mathrm{~g} / 10 \mathrm{~mL}$ and Rompun ${ }^{\circledR}$ (xylazine hydrochloride) $2 \mathrm{~g} / 100 \mathrm{~mL}$, in a proportion of 3:2, at a dose of $0.09 \mathrm{~mL} / 100 \mathrm{~g}$ and $0.06 \mathrm{~mL} / 100 \mathrm{~g}$ of body weight, respectively, via the intramuscular route. The anterior region of the thorax was trichotomized to ensure greater effectiveness of the stimulation and of the electrode placement. Electrical stimulation was performed daily for 20 minutes, always in the morning, during 7 consecutive days, with a frequency of $50 \mathrm{~Hz}$ (cycles per second), a $\mathrm{T}_{\text {on }}$ of 2 seconds (contraction time), a $\mathrm{T}_{\text {off }}$ of 2 seconds (relaxation time), and a phase width (pulse duration) of 0.4 milliseconds (ms). The intensity (pulse amplitude) was standardized at 5.0 milliamps (mA), from the visualization of muscle contraction, adding $1.0 \mathrm{~mA}$ to the current every 3 minutes, thereby minimizing the diaphragmatic accommodation ${ }^{8}$.

The equipment used for the electrical stimulation was the Dualpex 961 (QUARK ${ }^{\circledR}$ Medical Products, $\mathrm{SP}, \mathrm{Brazil)}$, in addition to two silicon-carbon electrodes (with an area of $1.5 \times 2.0 \mathrm{~cm}$ each) and a coupling gel. The two electrodes were placed bilaterally on the lateral region of the thorax between the 4th and 6th ribs, at the midpoint between the elbow and the last rib of the animal. This region is close to the lateral branches of the phrenic nerve, which innervate the diaphragmatic domes. On the 8th day, the animals were sacrificed by decapitation.

\section{Histomorphometric analysis}

Five segments of the lung were removed and fixed in a buffered solution of $10 \%$ formaldehyde, then subsequently underwent dehydration in ethyl alcohol, clearing in xylene, and inclusion in paraplast. Non-serial $6-\mu \mathrm{m}$-thick sections were obtained and processed for hematoxylin-eosin (HE) staining and were mounted on permanent slides with Entellan ${ }^{\circledR}$ (Merck 107961, Darmstadt, Germany).

Lung images were captured by an Olympus BX41 camera attached to an Olympus U-KPA - Japan 
microscope, which was integrated to a microcomputer equipped with an image-analysis software Image Proplus 6.2 (Media Cybernects $^{\circledR}$, Silver Spring, MD, USA). To evaluate the area density of the aerial portion of the pulmonary parenchyma, images were obtained only from the aerial part, alveoli, alveolar sacs, and alveolar ducts, excluding the bronchi, bronchioles, and large blood vessels.

Five lung fragments per animal, five slices per fragment, and five areas per section, totaling 125 images per animal, were selected. All the blinded slides were analyzed by a single researcher for all the variables studied.

The density of the alveolar area was measured through point-counting planimetry, according to the method of Mandarin-de-Lacerda et al. ${ }^{14}$. A checkered grid with 165 intersections was superimposed on the images, and the intersection points coinciding with the alveolar area were counted.

The data in percentages were calculated as follows:

$\frac{\text { Number of intersections coinciding with the alveolar area }}{\text { Total number of intersections }} \times 100=165$

For the quantification of the pulmonary parenchyma cells, a light microscope with an 100x objective, adapted with a reticle eyepiece (Carl Zeiss 10x/18 KF), was used. The number of fibroblasts, leukocytes, and macrophages present in the alveolar septum divided into eight areas of $1,000 \mu \mathrm{m}^{2}$, totaling $8,000 \mu \mathrm{m}^{2}$ per animal, were quantified.

\section{Immunohistochemical analysis}

Non-serial 6- $\mu \mathrm{m}$-thick sections were also collected on silanized slides for detecting 8-isoprostane-PGF2 (8-iso-PGF-2 $\alpha$ ). The antibody Anti-8-epi-PGF-2 $\alpha$ (Oxford Biomedical Research, Rochester Hills, MI, USA) was used in a dilution of 1:500. The blocks were dewaxed and washed seven times (for 5 minutes each) with $3 \% \mathrm{H}_{2} \mathrm{O}_{2}(10 \mathrm{~V})$ to inhibit the endogenous peroxidase activity. After rinses in PBS and water, antigen retrieval was performed with trypsin for 20 minutes, followed by three rinses (for 3 minutes each) in PBS.

The sections were incubated with Anti-8-epiPGF- $2 \alpha$ diluted in BSA overnight. After PBS rinsing, Vectastain ABC Kit (Vector Elite PK-6105, Burlingame, CA, USA) was used as a secondary antibody, and the 3,3-diaminobenzidine (DAB) (Sigma Chemical Co., St. Louis, MO, USA) was used as chromogen. The sections were then counterstained with Harris hematoxylin (Merck) ${ }^{15}$.
To quantify the percentage of the oxidation area, a Nikon OPI 10x/20 ocular and a 40x objective were used. The ocular had 100 points for counting the brown-stained areas (\% oxidation area). Thus, 25 areas of 55,225 $\mu \mathrm{m}^{2}$ (totaling 1,380,625 $\mu \mathrm{m}^{2}$ ) per animal were counted.

\section{Statistical analysis}

The Shapiro-Wilk test was applied in the statistical analysis to verify the normality of the sample. The parametric one-way ANOVA test, followed by the Bonferroni test, was chosen for the statistical analysis due to the normal distribution of the data, which are presented as the mean and standard deviation (SD). The analyses were processed by the SPSS ${ }^{\circledR}$ 13.0 software (Chicago, USA), using a significance level of $5 \%$.

\section{Results}

The morphometric analysis of the lung tissue (Table 1) revealed that, compared with group $\mathrm{C}$, group B had a significant reduction of $38.43 \%$ in the density of the alveolar area. The morphometric data of the TEDS group were not different from the $\mathrm{C}$ group.

TEDS treatment of the $\mathrm{B}+$ TEDS group prevented the loss of alveolar area, compared with the group treated only with B, whereas there was no difference compared with group $\mathrm{C}$. These changes are presented in Figure 1.

Regarding the numerical profile of the cells within the pulmonary parenchyma, in Group B, both leukocytes and macrophages displayed significant increases of $150 \%$ and $40 \%$, respectively, compared with group $\mathrm{C}$. The TEDS treatment did not affect the number of cells in the lung tissue, and even in the $\mathrm{B}+$ TEDS group, the values were equal to those of group $\mathrm{C}$. The number of fibroblasts in the $\mathrm{B}+\mathrm{TEDS}$ group displayed a significant reduction compared with that of group B (Table 2).

The percentage of the lipidic peroxidation substrate area (Figure 2), as evidenced by the 8-isoPGF-2 $\alpha$, also displayed a significant increase of $184 \%$ in group B compared with group C. However, after the TEDS treatment in the B + TEDS group, this area percentage was lower, with no significant difference in group C (Figure 3). 


\section{- Discussion}

The results of the present study demonstrated that B treatment promoted a reduced density of the alveolar area and an increased number of leukocytes and macrophages in rat pulmonary tissue. However, when the treatment was combined with the early application of TEDS, these variables did not differ from those of the $\mathrm{C}$ group.

Table 1. Density of the alveolar area (\%) of the control (C), stimulated (TEDS), bleomycin (B), and bleomycin + TEDS (B + TEDS) groups.

$\begin{array}{cc}\text { Groups }(\mathbf{n}=5) & \text { Density of the alveolar area }(\boldsymbol{\%}) \\ \text { C } & 51.3 \pm 3.4 \\ \text { TEDS } & 49 \pm 2.5 \\ \text { B } & 31.6 \pm 5.2 * \dagger \\ \text { B + TEDS } & 45.3 \pm 8.3 \dagger\end{array}$

Values are expressed as the mean \pm standard deviation. Statistically significant difference compared with $\mathrm{C}^{*}, \mathrm{~B} \dagger$, and TEDS $\$(\mathrm{p}=0.001)$.
In the literature, there are several animal-model studies in which intratracheal B administration induces acute lung inflammation, thereby promoting the release of free radicals that culminate in chronic fibrosis at a later stage. Because of this side effect, $\mathrm{B}$ is widely used in research to induce pulmonary fibrosis because this condition is similar to human pulmonary fibrosis; when intratracheally instilled, B causes acute interstitial inflammation with a predominance of neutrophils and macrophages ${ }^{16-19}$.

The present investigation corroborates the findings in the literature, and the presence of inflammatory reactions and the reduction in the alveolar area after B instillation was confirmed through histological analysis because an increased number of inflammatory cells (such as leukocytes and macrophages) was observed; however, the analysis was performed during the acute phase of the interstitial inflammation. Thus, compared with the $\mathrm{C}$ group, there was no significant increase in the number of fibroblasts, which are the cells responsible for

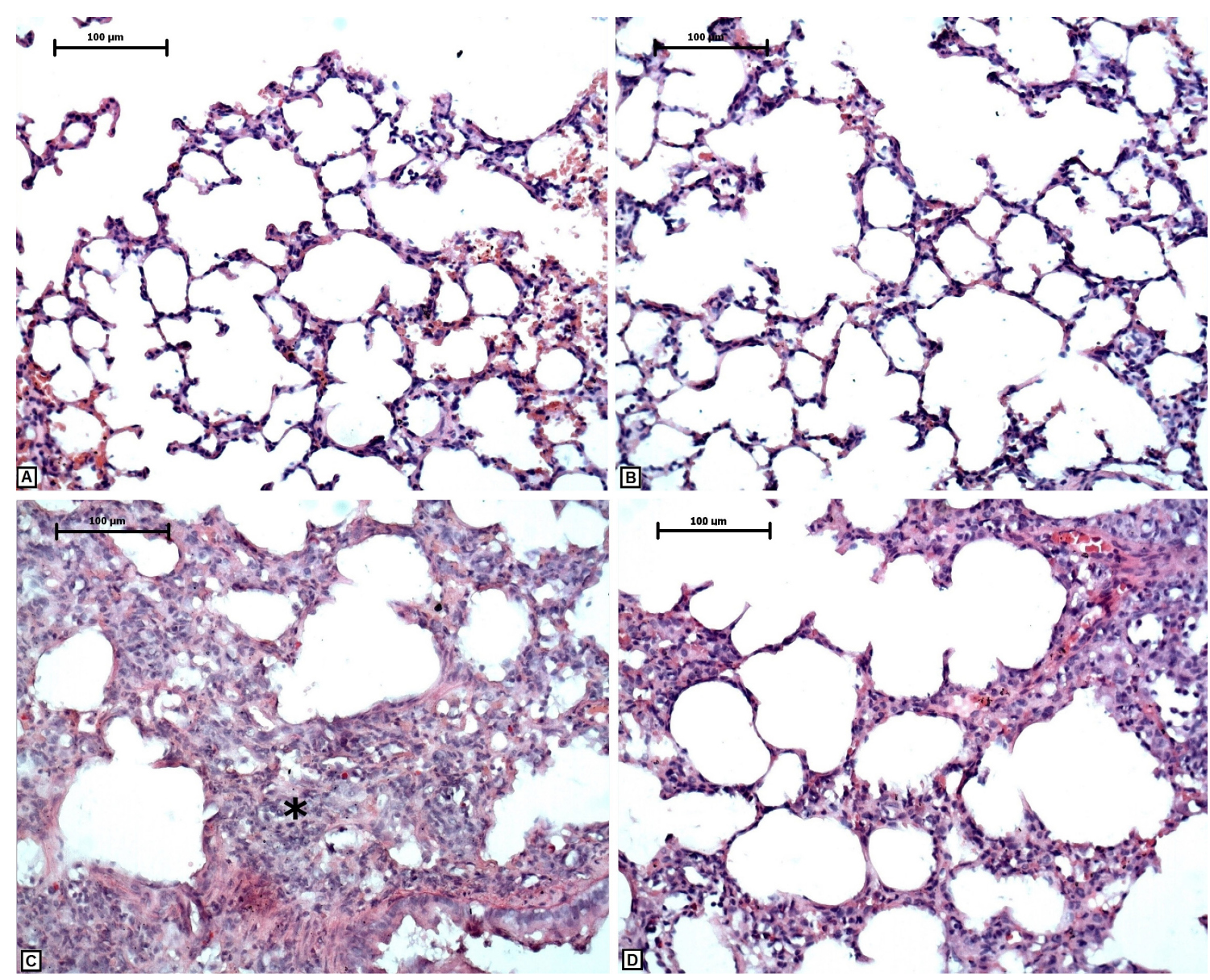

Figure 1. Photomicrograph of the following lung groups: control (A), stimulated (B), bleomycin (C), and bleomycin + TEDS (D). The interalveolar-septum thickening $(*)$ may be observed. Hematoxylin-eosin, 200x, bar=100 $\mu \mathrm{m}$. 


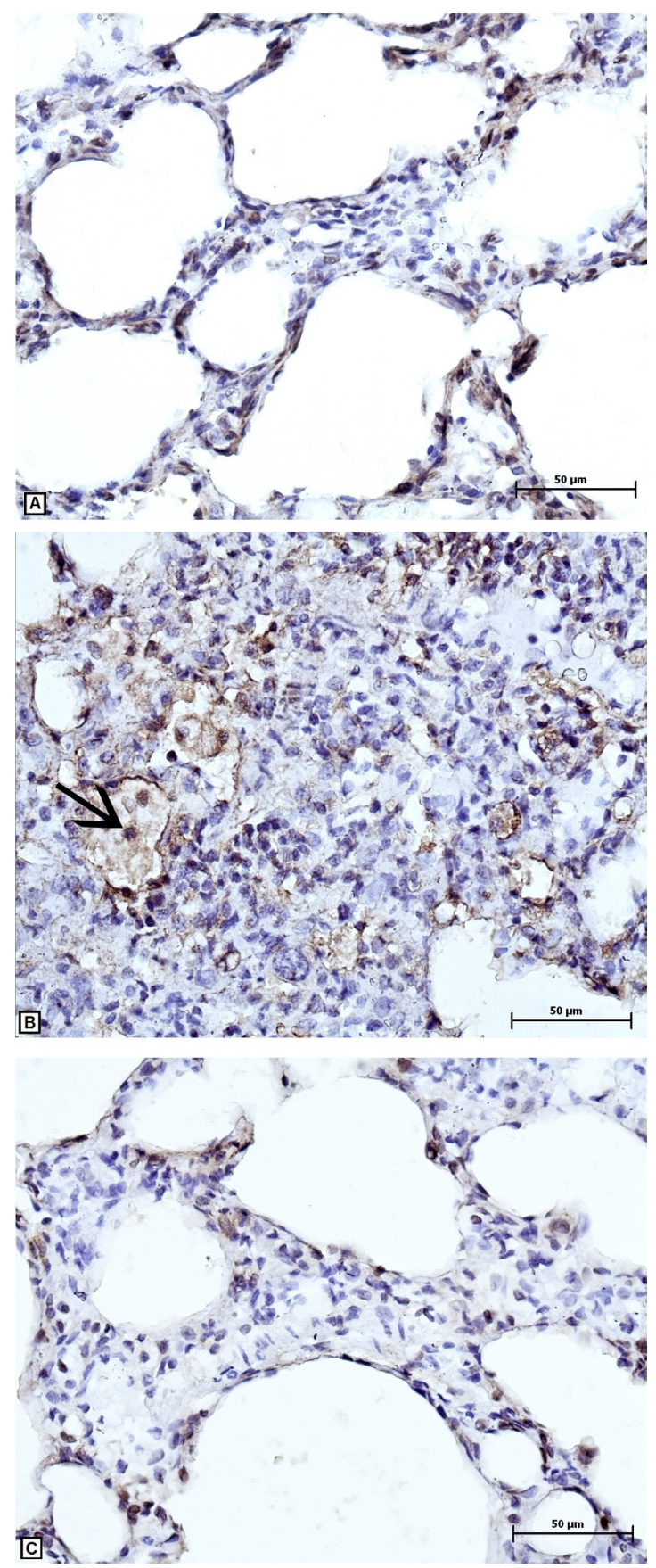

Figure 2. Photomicrograph of the lung parenchyma of rats in the following groups: control (A), bleomycin (B), and bleomycin + TEDS (C). Lipid peroxidation is evidenced by the brown color formed by the chromogen. The arrow indicates the macrophages. (Hematoxylin Harris, 400x, bar=50 $\mu \mathrm{m}$ ).

synthesizing and remodeling the extracellular matrix (ECM), thus exhibiting a chronic inflammatory reaction ${ }^{20}$.

Regarding the number of cells present in the interalveolar septum, the B group displayed an increase number of pro-inflammatory cells, such as
Table 2. Number of fibroblasts, leukocytes, and macrophages present in the interalveolar septum with pulmonary inflammation in the control group (C), stimulated group (TEDS), bleomycin group (B), and the bleomycin + TEDS group (B + TEDS).

\begin{tabular}{cccc}
\hline Groups $(\mathbf{n = 5})$ & Fibroblasts & Leukocytes & Macrophages \\
C & $7.4 \pm 0.3$ & $0.7 \pm 0.1$ & $0.5 \pm 0.1$ \\
TEDS & $7.8 \pm 0.1$ & $0.8 \pm 0.1$ & $0.9 \pm 0.1$ \\
B & $8.1 \pm 0.4$ & $1.9 \pm 0.4 * \dagger$ & $1.4 \pm 0.2^{*}$ \\
B + TEDS & $7.1 \pm 0.3 \ddagger$ & $0.9 \pm 0.1 \ddagger$ & $0.5 \pm 0.1 \ddagger$ \\
\hline
\end{tabular}

Values are expressed as the mean \pm standard deviation. Statistically significant difference compared with $\mathrm{C}^{*}$, TEDS $\dagger$, and $\mathrm{B} \ddagger ;(\mathrm{p}<0.05)$.

8-iso-PGF2 $\alpha$

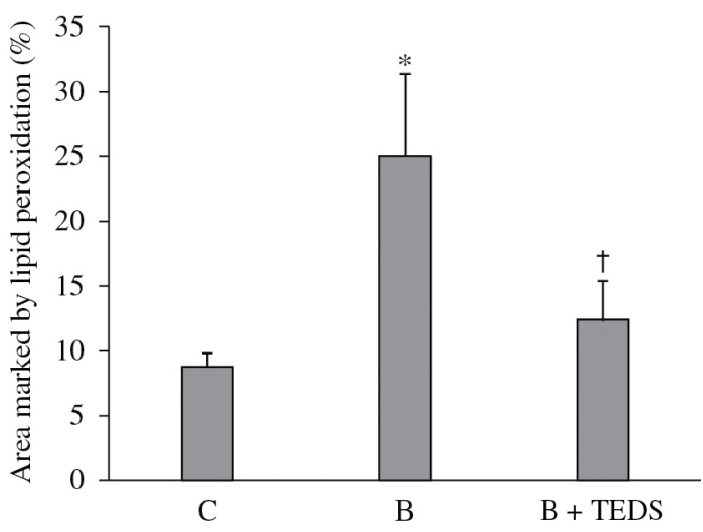

Figure 3. Area marked by lipid peroxidation 8 -iso-PGF- $2 \alpha$ in the control group (C), bleomycin group (B), and TEDS + bleomycin group (B + TEDS). Values are expressed as the mean \pm standard deviation. Statistically significant difference compared with $\mathrm{C}^{*}$ and $\mathrm{B} \dagger(\mathrm{p}<0.01)$.

leukocytes and macrophages. During the installed inflammatory process, there is alveolar damage, alveolar macrophage activation, and the influx of cells such as monocytes and lymphocytes-in addition to the release of growth factors that stimulate fibroblast proliferation, leading to extracellular collagen deposition and fibrosis at a later stage ${ }^{21}$.

The histological analysis of the lungs of rats treated with B + TEDS (7 days after the instillation of a single dose of $\mathrm{B}$ ) revealed a significant reduction in the deleterious effects of the drug, with recovery of the alveolar area. Metabolically, the respiratory muscles benefit from this feature, promoting an increase in the uptake of metabolizable substrates and enzyme activation, in addition to muscular strengthening ${ }^{7,11,22}$.

Cancelliero et al. ${ }^{7}$ observed improved energetic conditions of the respiratory muscles with the application of TEDS, as evidenced by an increase in the diaphragmatic (42.85\%), intercostal (81.2\%), 
pectoralis $(96.7 \%)$, and abdominal $(104.5 \%)$ glycogen concentrations.

It is possible that, because of the TEDS-induced muscle contraction in the respiratory muscles after the B instillation, there was an increase in the blood flow, facilitating the removal of the B-induced ROS.

The isoprostanes (8-iso-PGF- $2 \alpha$ ) correspond to the end product of lipid peroxidation, in which phospholipids hydrolysis of the cell membrane occurs through a nonenzymatic reaction with arachidonic acid peroxidation ${ }^{23,24}$.

The present results demonstrated a significant increase in the percentage of the area marked with 8-iso-PGF-2 $\alpha$ in the B group, indicating increased oxidative stress in this group. This finding coincides with the increased number of alveolar macrophages found in the same group, and these cells have an important role in the induction of pulmonary fibrosis because they release a variety of substances, including cytokines and ROS, that lead to apoptosis and/or the increased regulation of transforming growth factor TGF- $\beta^{25}$.

Hong et al. ${ }^{26}$ have shown that the mitochondrial permeability of alveolar macrophages and lung epithelial cells is involved in the toxicity and types of cell injury. When exposed to $\mathrm{B}$, there is a loss of the mitochondrial membrane potential of alveolar macrophages, which is caused by the accumulation of cytochrome $\mathrm{c}$ in the cytosol and by the increase in ROS formation, leading to cell apoptosis. All these effects were attenuated when treated with an antioxidant, such as ambroxol, which is the active ingredient of Mucosolvan ${ }^{\circledR}$.

To reinforce this thesis, $\mathrm{Asai}^{27}$ used the antioxidant edaravone to treat rabbits with pulmonary fibrosis induced by $\mathrm{B}$. The results revealed attenuation of the inflammatory infiltrate in the interalveolar septum, apoptosis, and the synthesis of TGF- $\beta$, demonstrating that the B-induced injury is a result of ROS production.

Telesi and Machado ${ }^{28}$ found that aerobic physical activity of mild-to-moderate intensity increases the antioxidant defenses, which are designed to inhibit or reduce the deleterious effects caused by free radicals. However, exhaustive physical activity increases oxidative damage, whereas moderate physical activity can reduce the effect of oxidative stress in tissues ${ }^{12}$.

The results from the B + TEDS group revealed a reduction in these oxidative stress areas. Although TEDS is not a physical exercise, the muscle contraction generated by the electric current was able to protect the lung tissue from the inflammatory process induced by B. Thus, in addition to the fact that this pathological condition can be treated with pharmacologic agents and physical exercise, as observed in the above-mentioned studies, the early application of TEDS (as a physical therapeutic) may facilitate the prevention of B-induced inflammatory processes in the lung tissue.

These results confirm other histopathological analyses, in which the pulmonary tissues from the group that received treatment with B + TEDS presented area densities and numbers of fibroblasts, leukocytes, and macrophages that were all similar to the $\mathrm{C}$ group.

The present investigation confirms the effectiveness of this resource in preventing the onset of pulmonary fibrosis, thereby confirming the initial hypothesis. In addition, this study highlights the importance of obtaining data about these physiological and morphological effects in an animal model because it is impossible to perform such invasive analyses in humans. Moreover, because this resource was recently adapted to the animal model, there are currently no published reports regarding its effect on the pulmonary tissue.

Other perspectives may be explored in continuation of this work, such as a therapeutic treatment with TEDS in animals with lungs already damaged by $\mathrm{B}$, in addition to the analyses related to the oxidantantioxidant system; such investigations would further elucidate these results-particularly the findings related to the muscle-contraction mechanism of action generated by TEDS for preventing pulmonary inflammatory processes. It is hoped that these studies will support and contribute to developing the field of respiratory physical therapy.

Regarding the present investigation's limitations, there was no analysis of muscular (mainly diaphragmatic) interleukins, which would have furthered the understanding of the muscle contraction generated by TEDS.

Therefore, it can be concluded that B treatment promotes a reduction in the alveolar area by inducing the inflammatory process but that early application of the TEDS physical therapeutic resource may prevent the deleterious effects of this drug.

\section{References}

1. Yamauchi K, Kasuya Y, Kuroda F, Tanaka K, Tsuyusaki $\mathrm{J}$, Ishizaki S, et al. Attenuation of lung inflammation and fibrosis in CD69-deficient mice after intratracheal bleomycin. Respir Res. 2011;12(131):1-10.

2. Hagiwara SI, Ishii Y, Kitamura S. Aerosolized administration of $\mathrm{N}$ - acetylcysteine attenuates lung fibrosis induced by bleomycin in mine. Am J Respir Crit 
Care Med. 2000;162(1):225-31. PMid:10903246. http:// dx.doi.org/10.1164/ajrccm.162.1.9903129

3. Tapkire R, Kathiresan N, Satheesan B. Bleomycin induced urethral stricture in Hodgkin's disease. Indian J Urol. 2009;25(3):398-400. PMid:19881140 PMCid:PMC2779969. http://dx.doi. org/10.4103/0970-1591.56180

4. Mouratis MA, Aidinis V. Modeling pulmonary fibrosis with bleomycin. Curr Opin Pulm Med. 2011;17(5):35561. PMid:21832918. http://dx.doi.org/10.1097/ MCP.0b013e328349ac2b

5. Stevenson CS, Koch LG, Britton SL. Aerobic capacity, oxidant stress, and chronic obstructive pulmonary disease. Anew take on an old hypothesis. Pharmacol Ther. 2006;110(1):71-82. PMid:16343638. http://dx.doi. org/10.1016/j.pharmthera.2005.09.006

6. Costa D, Cancelliero KM, Polacow MLO, Silva CA. Metabolic profile of respiratory muscles of rats with bleomycin - induced pulmonary fibrosis: relationship with oxidative stress. J Chin Clin Med. 2008;3(3):123-32.

7. Cancelliero KM, Costa D, Silva CA. Estimulação diafragmática elétrica transcutânea melhora as condições metabólicas dos músculos respiratórios de ratos. Rev Bras Fisioter. 2006;10(1):59-61. http://dx.doi.org/10.1590/ S1413-35552006000100008

8. Costa D, Cancelliero KM, Campos GE, Salvini TF, Silva CA. Changes in types of muscle fibers induced by transcutaneous electrical stimulation of the diaphragm of rats. Braz J Med Biol Res. 2008;41(9):809-11. PMid:18820771.

9. Costa D, Forti EMP, Barbalho-Moulin MC, Rasera-Junior I. Study on pulmonary volumes and thoracoabdominal mobility in morbidly obese women undergoing bariatric surgery, treated with two different physical therapy methods. Rev Bras Fisioter. 2009;13(4):294-301. http:// dx.doi.org/10.1590/S1413-35552009005000041

10. Nascimento P, Aquim EE. A aplicação da eletroestimulação transcutânea diafragmática em indivíduos normais. Fisioter Bras. 2000;1(1):15-8.

11. Forti EMP, Ike D, Barbalho-Moulim M, Rasera I Jr, Costa D. Effects of chest physiotherapy on the respiratory function of postoperative gastroplasty patients. Clinics. 2009;64(7):683-9. PMid:19606246 PMCid:PMC2710443. http://dx.doi.org/10.1590/ S1807-59322009000700013

12. Reid MB. Redox modulation of skeletal muscle contraction what we know and what we don't. J Appl Physiol. 2007;103(6):1921-8.

13. Beller TC, Friend DS, Maekava A, Lam BK, Austen KF, Kanaoka Y. Cysteinyl leukotriene 1 receptor controls the severity of chronic pulmonary inflammation and fibrosis. Proc Natl Acad Sci USA. 2004;101(9):304752. PMid:14970333 PMCid:PMC365742. http://dx.doi. org/10.1073/pnas.0400235101

14. Mandarin-de-Lacerda CA, Fernandes-Santos C, Aquila MB. Image analysis and quantitative morphology. Methods Mol Biol. 2010;611:211-25. PMid:19960334. http://dx.doi. org/10.1007/978-1-60327-345-9_17
15. Angeli P, Prado CM, Xisto DG, Silva PL, Pássaro CP, Nakazato HD, et al. Effects of chronic L-NAME treatment lung tissue mechanics, eosinophilic and extracellular matrix responses induced by chronic pulmonary inflammation. Am J Physiol Lung Cell Mol Physiol. 2008;294(6):L1197-205. PMid:18359886. http:// dx.doi.org/10.1152/ajplung.00199.2007

16. Di Paola R, Talero E, Galuppo M, Mazzon E, Bramanti P, Motilva V, et al. Adrenomedullin in inflammatory process associated with experimental pulmonary fibrosis. Respir Res. 2011;12(1):41. PMid:21477302 PMCid:PMC3079622. http://dx.doi. org/10.1186/1465-9921-12-41

17. Zhang D, Huang C, Yang C, Liu RJ, Wang J, Niu J, et al. Antifibrotic effects of curcumin are associated with overexpression of cathepsins $\mathrm{K}$ and L in bleomycin treated mice and human fibroblasts. Respir Res. 2011;12(1):154. PMid:22126332 PMCid:PMC3260240. http://dx.doi. org/10.1186/1465-9921-12-154

18. Lawrenz J, Herndon B, Kamal A, Mehrer A, Dim DC, Baidoo C, et al. Dietary Flaxseed Oil Protects against Bleomycin-Induced Pulmonary Fibrosis in Rats. Pulm Med. 2012;2012:457031. PMid:22919480 PMCid:PMC3423954. http://dx.doi. org/10.1155/2012/457031

19. Moeller A, Rodriguez-Lecompte JC, Wang L, Gauldie J, Kolb M. Models of pulmonary fibrosis. Drug Discov Today Dis Models. 2006;3(3):243-8. http://dx.doi. org/10.1016/j.ddmod.2006.09.006

20. Tang X, Peng R, Ren Y, Apparsundaram S, Deguzman J, Bauer CM, et al. BET Bromodomain Proteins Mediate Downstream Signaling Events Following Growth Factor Stimulation in Human Lung Fibroblasts and are Involved in Bleomycin-Induced Pulmonary Fibrosis. Mol Pharmacol. 2013;83(1):283-93. PMid:23115324. http:// dx.doi.org/10.1124/mol.112.081661

21. Blink BVD, Jansen HM, Peppelenbosch MP. Idiopathic Pulmonary Fibrosis: Molecular Mechanisms and Possible Therapeutic Strategies. Arch Immunol Ther Exp (Warsz). 2000;48(6):539-45.

22. Guirro RRJ, Nunes CV, Davini R. Comparação dos efeitos de dois protocolos de estimulação elétrica neuromuscular sobre a força muscular isométrica do quadríceps. Rev Fisioter Univ São Paulo. 2000;7(1/2):10-5.

23. Lima ES, Abdalla DSP. Peroxidação lipídica: mecanismos e avaliação em amostras biológicas. Rev Bras Cienc Farm. 2001;37(3):293-03.

24. Cavalcante AGM, Bruin PFC. O papel do estresse oxidativo na DPOC: conceitos e atuais perspectivas. J Bras Pneumol. 2009;35(12):1227-37. PMid:20126926. http://dx.doi.org/10.1590/S1806-37132009001200011

25. Fujita M, Mizuta Y, Ikegame S, Ouchi H, Ye Q, Harada E, et al. Biphasic effects of free radical scavengers against bleomycin-induced pulmonary fibrosis. Pulm Pharmacol Ther. 2008;21(5):805-11. PMid:18655842. http://dx.doi. org/10.1016/j.pupt.2008.06.006

26. Hong JS, Ko HH, Han ES, Lee CS. Inhibition of bleomycin - induced cell death in rat alveolar macrophages and human lung epithelial cells by ambroxol. 
Biochem Pharmacol. 2003;66(7):1296-306. http://dx.doi. org/10.1016/S0006-2952(03)00448-9

27. Asai $T$. The specific free radical scavenger edaravone suppresses bleomycin - induced acute pulmonary injury in rabbits. Clin Exp Pharmacol Physiol. 2007;34(1-2):22-6. PMid:17201731. http:// dx.doi.org/10.1111/j.1440-1681.2007.04528.x

28. Telesi M, Machado FA. A influência do exercício físico e dos sistemas antioxidantes na formação de radicais livres no organismo humano. Rev Saúde Biol. 2008;3(1):40-9.

\section{Correspondence}

\section{Laisa Antonela dos Santos}

Universidade Metodista de Piracicaba

Programa de Pós-Graduação em Fisioterapia

Rod. do Açúcar, Km 156

CEP 13400-911, Piracicaba, SP, Brasil

e-mail: laisa_antonela@hotmail.com 